\title{
EXPERIMENTAL STUDY ON CORROSION PREVENTION WITH REBARS ALONG WITH FIBRE IN R C SLABS
}

\author{
Yazeed Ali.P ${ }^{1}$, S.Kanchana ${ }^{2}$, Anju K.S ${ }^{3}$,Shyam.P ${ }^{4}$, \\ ${ }^{1} P G$ Scholar, Department of Civil Engineering, RVS Technical Campus, Coimbatore, yazeed10ce51@gmail.com \\ ${ }^{2}$ Associate Professor, Department of Civil Engineering, RVS Technical Campus, Coimbatore, kash@gmail.com \\ ${ }^{3} P G$ Scholar, Department of Civil Engineering, RVS Technical Campus, Coimbatore, anjuks378@gmail.com \\ ${ }^{4}$ PG Scholar, Department of Civil Engineering, RVS Technical Campus, Coimbatore, shyampbal@gmail.com
}

\begin{abstract}
All materials or products, plants, constructions and building made of structural elements are subjected to physical wear during use. Corrosion is a multi- billion dollar problem. Corrosion causes deterioration of material and leads to destruction of structures ultimately affects the environment. Corrosion is a chemical or electrochemical phenomenon which can attack any metal or substances through reaction by the surrounding environment. The second is conservation, applied primarily to metal resources, the world's supply of which is limited. The project is aimed at preventing corrosion that is minimising the rate of corrosion using polypropylene fibre and epoxy coating. In this work an attempt is planned to study the effects of fibres in concrete and to study the coating provided to the reinforcement. To accelerate the corrosion for a short term process of impressed current is induced. In this project it is aimed to study the effect of coating given to the reinforcement and effect of adding fibre in the concrete.
\end{abstract}

Keywords: Fibre, Compressive Strength, Flexural Strength.

\section{INTRODUCTION}

Concrete is widely and commonly used man made construction material in the world. It is obtained by mixing cementitious material, water and aggregate in required proportions. The mixture when placed forms and allowed to cure hardness into a rock like mass known as concrete. It has high compressive strength and low tensile strength. To develop the tensile stresses the concrete is strengthened by the steel bars called reinforced cement concrete.

Concrete is the main source used throughout the world for construction.. Today, the large numbers of civil infrastructures around the world in a state of serious deterioration due to carbonation, chloride attack, etc.

Corrosion of reinforcement is the main reason for the destruction of structural concrete. It causes a major economic cost for maintenance. The effect of this deterioration on residual capacity is therefore a matter of concern to those charged with ensuring safe operation of concrete structures.

\section{MATERIALS AND METHODS}

\subsection{Cement}

Cement is the most important constituent of concrete, in that it forms the binding medium for the discrete ingredients made out of naturally occurring raw materials and sometimes blended with industrial wastes. OPC cement of 53 grade is used for experimental study.

\subsection{Fine Aggregate}

The fine aggregates smaller than $4.75 \mathrm{~mm}$ size are used. River sands are generally used as fine aggregate river sand was used in preparing the concrete as it was locally available in sand quarry. The specific gravity and water absorption were found to be 2.7 and 1,0\% respectively, with sieve analysis data and fineness modulus value of sand confirms to grading zone II as per IS 383-2009.

\subsection{Coarse Aggregate}

The coarse aggregate retained on $4.75 \mathrm{~mm}$ sieve are used. Crushed stone and natural gravel are the common materials used as coarse aggregate for concrete. It is obtained by crushing various types of granites, schist and gneiss, crystalline and lime stone and good quality sand stones. Concrete made with sand stone aggregate give trouble due to cracking because of high degree of shrinkage. For coarse aggregate crushed $20 \mathrm{~mm}$, normal size grade aggregate was used. The specific gravity and water absorption were found to be 2.7 and $0.5 \%$ respectively.

\subsection{Fibre}

Polypropylene fibres are used to improve the protection of concrete. It is a $100 \%$ synthetic textile fibre. It is formed by $85 \%$ propylene. This fibre is in white colour. The specific gravity of fibre is 0.91 . The length of the fibre used is $2 \mathrm{~cm}$.

\subsection{Reinforcing steel}

Fe 415 HYSD bars of $8 \mathrm{~mm}$ diameter were used as reinforcement in the slabs. 


\subsection{Coating material}

Epoxy coating is used as the coating material.

\subsection{Casting of slabs}

M 25 concrete have been designed as per IS code. The mix proportion of 1:1.48:2.88 for M25 concrete. The mix designed has been prepared and poured in the form of slab. The element has been demoulded after 24 hours and kept immersed in water for 28 days curing.

\section{METHODS USED TO INDUCE THE CORROSION}

The method used to induce corrosion is Galvan static method (accelerated corrosion method)

\section{ACCELERATED CORROSION TEST}

In M25 grade 8 slabs were casted and the insulated copper wires are connected to the main reinforcement of the slabs at the corresponding points while casting. The metal above the steel in galvanic series can be used as sacrificial anode current is passed in reinforcement of slabs after filling the top of the slabs with salt water, which contains $3 \%$ of sodium chloride. The current is passed from a DC power supply. Positive terminal of the DC power supply is connected to the main reinforcement of the slabs and negative terminal is connected to the steel plate, which also kept immersed in the salt water.

The density of current is around 1.8 to $2.0 \mathrm{~mA} / \mathrm{cm}^{2}$ of the surface area of the rod was induced corrosion. The slabs placed in the tank were subjected to a current density of 1.8 $\mathrm{mA} / \mathrm{cm}^{2}$ from external D.C source. The stainless steel plate which acts as cathode was placed below the slab. The stainless steel plate was $1.5 \mathrm{~mm}$ thick. The current density was adjusted using knobs provided in D.C rectifier to maintain a constant current density throughout the test.

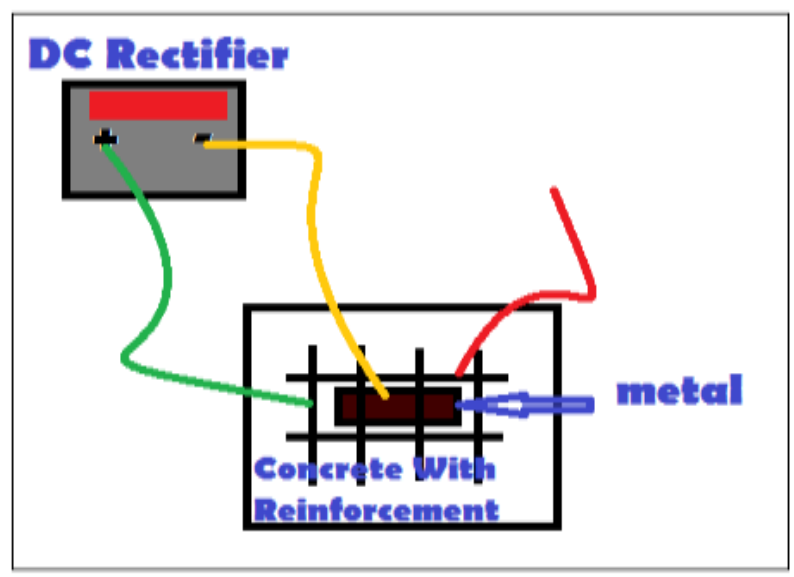

\section{HALF-CELL MEASUREMENT}

The objective of this method is to measuring the voltages that are present over the rebar in concrete. The half-cell consists of a hollow tube in a copper electrode and it is then immersed in copper sulphate solution. The bottom of the tube is porous and covers in a sponge material. The sponge that placed on a concrete can be permeated by the copper sulphate which allows an electrical potential to be measured. The objective of the method is to be measure the voltage difference between the rebar and the concrete over the rebar. Large negative 6oltage $(-350 \mathrm{mV})$ indicate that corrosion may be taking place. Voltage smaller than about $-250 \mathrm{mV}$ generally mean corrosion is not taking place.

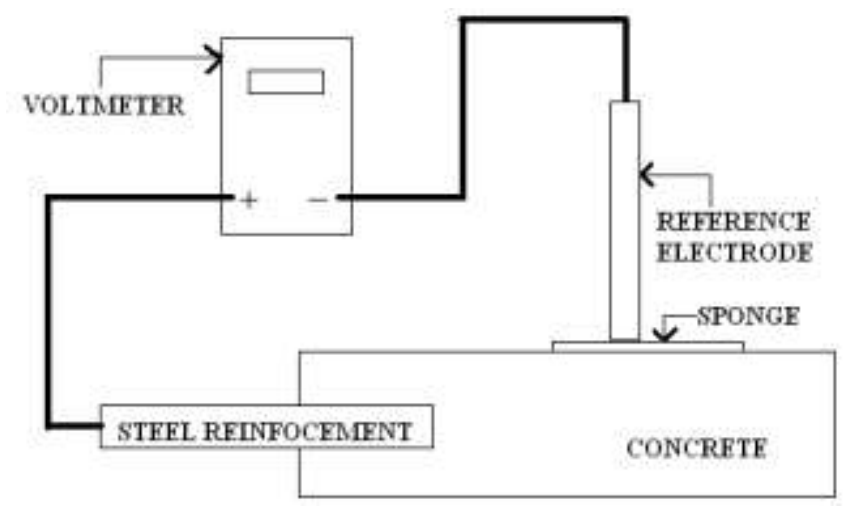

Fig 1. Half-Cell Measurement Diagram

\section{RESULT AND DISCUSSIONS}

\subsection{Compressive Strength}

The specimens used were standard cubes of size $500 * 500 * 500 \mathrm{~mm}$. Tests were conducted using compression testing machine of capacity 300T. The loading was applied gradually and the results have been tabulated as in table 1 .

Table 1. Characteristic Compressive strength for conventional and fibre concrete

\begin{tabular}{|c|c|c|c|}
\hline $\begin{array}{c}\text { Details of } \\
\text { specimen }\end{array}$ & $\begin{array}{c}\text { Compressive } \\
\text { strength for } \\
7 \text { days } \\
\left(\mathrm{N} / \mathrm{mm}^{2}\right)\end{array}$ & $\begin{array}{c}\text { Compressive } \\
\text { strength For } \\
14 \text { days } \\
\left(\mathrm{N} / \mathrm{mm}^{2}\right)\end{array}$ & $\begin{array}{c}\text { Compressive } \\
\text { strength for } \\
\text { 28days } \\
\left(\mathrm{N} / \mathrm{mm}^{2}\right)\end{array}$ \\
\hline Conventional & 23.88 & 25.61 & 27.11 \\
\hline With Fibre & 31.55 & 34.87 & 37.11 \\
\hline
\end{tabular}

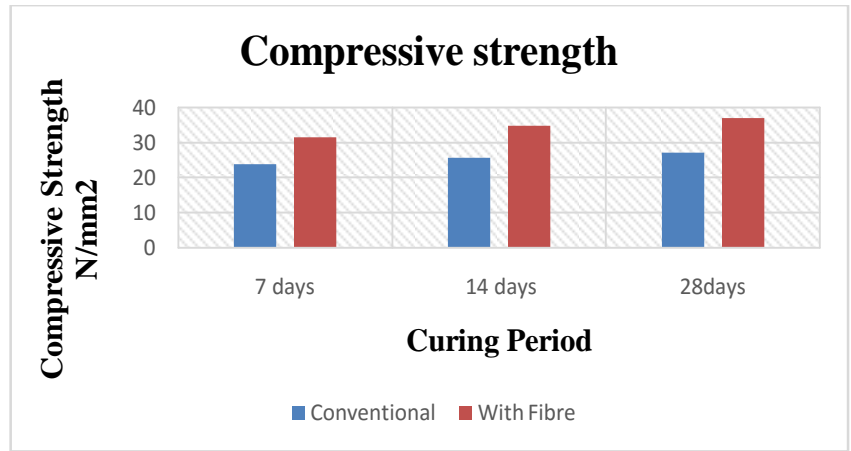

Fig 2. Chart comparing the compressive strength of conventional and fibre concrete 


\subsection{Split Tensile Strength}

This test is carried out by placing the standard cylinder specimen of diameter $150 \mathrm{~mm}$ and height $300 \mathrm{~mm}$ horizontally between the loading surface of the compression testing machine and the loading was applied until the failure of the cylinder. Table 2 shows the test result for split tensile strength concrete for M25 concrete.

Table 2. Split Tensile strength for conventional and fibre

\begin{tabular}{|c|c|c|c|}
\hline \multicolumn{1}{|c|}{ concrete } \\
specimen & $\begin{array}{c}\text { Split } \\
\text { Tensile } \\
\text { Strength } \\
\text { for 7 days } \\
\left(\mathrm{N} / \mathrm{mm}^{2}\right)\end{array}$ & $\begin{array}{c}\text { Split } \\
\text { Tensile } \\
\text { Strength } \\
\text { for } 14 \\
\text { days } \\
\left(\mathrm{N} / \mathrm{mm}^{2}\right)\end{array}$ & $\begin{array}{c}\text { Split } \\
\text { Tensile } \\
\text { Strength } \\
\text { for } 28 \\
\text { days } \\
(\mathrm{N} / \mathrm{mm} 2)\end{array}$ \\
\hline Conventional & 1.8 & 2 & 2.2 \\
\hline With Fibre & 2.5 & 2.7 & 3.0 \\
\hline
\end{tabular}

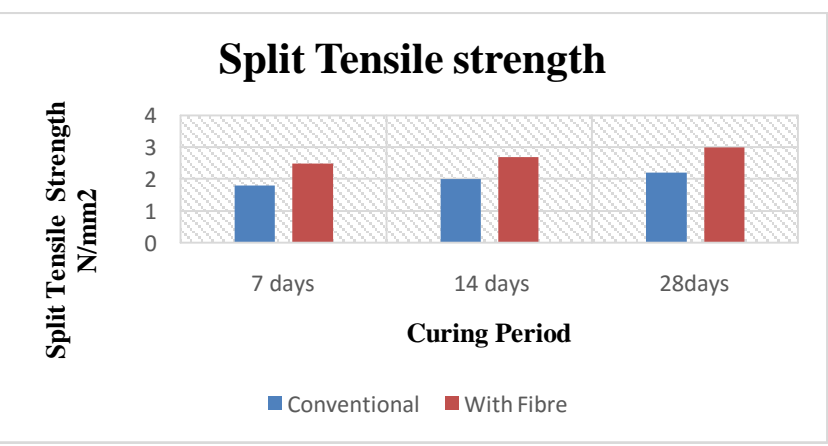

Fig 3. Chart comparing the split tensile strength of conventional and fibre concrete

\section{WEIGHT LOSS}

\section{Uncoated}

Table 3. Weight loss for uncoated reinforcement specimens.

\begin{tabular}{|c|l|c|c|c|}
\hline $\begin{array}{c}\text { S. } \\
\text { no }\end{array}$ & $\begin{array}{c}\text { Details of } \\
\text { specimen }\end{array}$ & $\begin{array}{c}\text { Initial } \\
\text { wt } \\
\text { (gms) }\end{array}$ & $\begin{array}{c}\text { Final } \\
\text { wt } \\
\text { (gms) }\end{array}$ & $\begin{array}{c}\% \\
\text { weight } \\
\text { loss }\end{array}$ \\
\hline 1 & M 25(con) & 175 & 164 & 6.28 \\
\hline 2 & M25 + FIBER & 178 & 166 & 6.74 \\
\hline
\end{tabular}

\section{Coated}

Table 4. Weight loss for coated reinforcement specimens.

\begin{tabular}{|c|l|c|c|c|}
\hline $\begin{array}{c}\text { S. } \\
\text { no }\end{array}$ & $\begin{array}{c}\text { Details of } \\
\text { specimen }\end{array}$ & $\begin{array}{c}\text { Initial } \\
\text { wt } \\
\text { (gms) }\end{array}$ & $\begin{array}{c}\text { Final } \\
\text { wt } \\
\text { (gms) }\end{array}$ & $\begin{array}{c}\% \\
\text { weight } \\
\text { loss }\end{array}$ \\
\hline 1 & M 25(con) & 189 & 182 & 3.70 \\
\hline 2 & M25 + FIBER & 186 & 181 & 2.68 \\
\hline
\end{tabular}

Table 5. Half-cell reading for uncoated conventional reinforcement

\begin{tabular}{|c|c|c|c|}
\hline \multirow{2}{*}{$\begin{array}{c}\text { Time } \\
\text { Intervals }\end{array}$} & \multicolumn{3}{|c|}{ M 25 } \\
\cline { 2 - 4 } & Trial I & Trial II & Trial III \\
\hline 0 & - & - & - \\
\hline 25 & 24 & 19 & 30 \\
\hline 50 & 54 & 64 & 113 \\
\hline 75 & 77 & 74 & 86 \\
\hline 100 & 110 & 116 & 118 \\
\hline 125 & 130 & 138 & 138 \\
\hline 150 & 153 & 167 & 178 \\
\hline
\end{tabular}

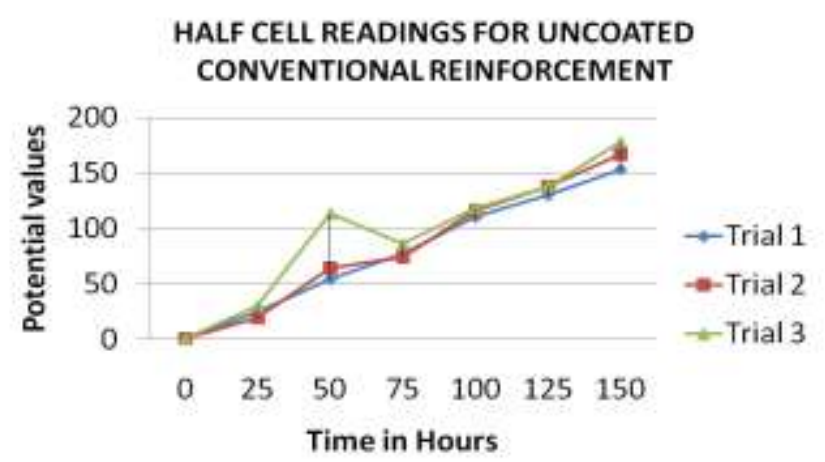

Fig 4. Half-cell reading for uncoated conventional reinforcement

Table 6. Half-cell reading for coated conventional reinforcement

\begin{tabular}{|c|c|c|c|}
\hline \multirow{2}{*}{$\begin{array}{c}\text { Time } \\
\text { Intervals }\end{array}$} & \multicolumn{3}{|c|}{ M 25 } \\
\cline { 2 - 4 } & Trial I & & Trial I \\
\hline 0 & - & - & - \\
\hline 25 & 178 & 180 & 196 \\
\hline 50 & 209 & 210 & 218 \\
\hline 75 & 210 & 220 & 222 \\
\hline 100 & 233 & 249 & 240 \\
\hline 125 & 259 & 264 & 289 \\
\hline 150 & 270 & 281 & 291 \\
\hline
\end{tabular}

HALFCELL READINGS FOR COATED CONVENTIONAL REINFORCEMENT

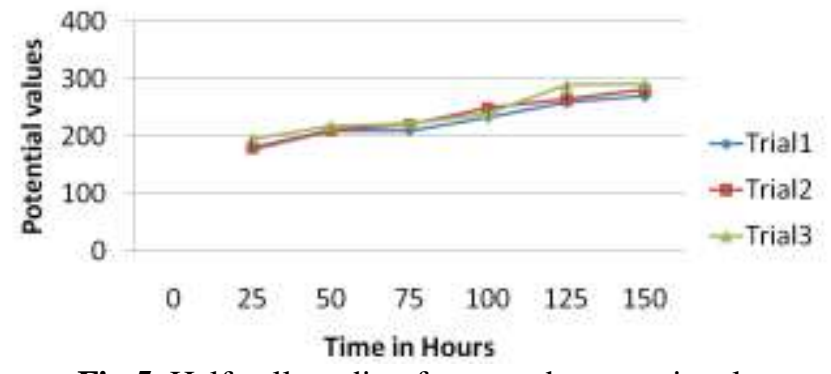

Fig 5. Half-cell reading for coated conventional reinforcement 
Table 7. Half-cell reading for uncoated reinforcement with fibre

\begin{tabular}{|c|c|c|c|}
\hline \multirow{2}{*}{$\begin{array}{c}\text { Time } \\
\text { Intervals }\end{array}$} & \multicolumn{3}{|c|}{ M 25 } \\
\cline { 2 - 4 } & Trial I & Trial II & Trial III \\
\hline 0 & - & - & - \\
\hline 25 & 192 & 170 & 170 \\
\hline 50 & 160 & 155 & 153 \\
\hline 75 & 249 & 263 & 235 \\
\hline 100 & 267 & 264 & 263 \\
\hline 125 & 317 & 332 & 312 \\
\hline 150 & 330 & 344 & 347 \\
\hline
\end{tabular}

\section{HALF CELL READINGS FOR UNCOATED} FIBER REINFORCEMENT

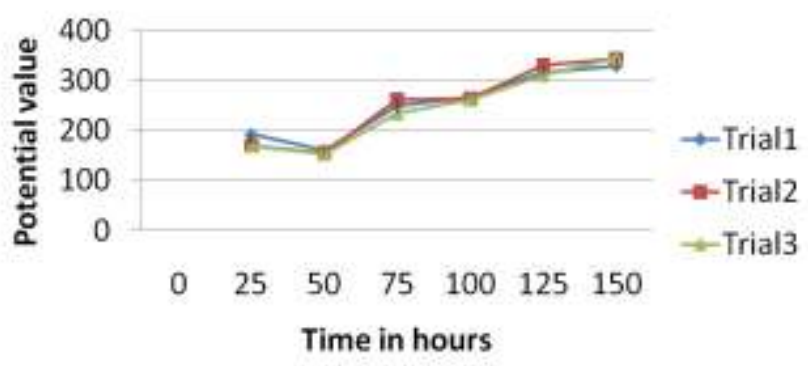

Fig 6. Half-cell measurement reading for uncoated reinforcement with fibre

From the Fig 4, it shows an increase in the potential value in the trial III, with increasing time interval.

Table 8. Half-cell reading for coated reinforcement with fibre

\begin{tabular}{|c|c|c|c|}
\hline \multirow{2}{*}{$\begin{array}{c}\text { Time } \\
\text { Intervals }\end{array}$} & \multicolumn{3}{|c|}{ M 25 } \\
\cline { 2 - 4 } & Trial I & Trial II & Trial III \\
\hline 0 & - & - & - \\
\hline 25 & 2 & 10 & 14 \\
\hline 50 & 19 & 37 & 21 \\
\hline 75 & 49 & 54 & 60 \\
\hline 100 & 79 & 83 & 94 \\
\hline 125 & 100 & 102 & 103 \\
\hline 150 & 131 & 168 & 154 \\
\hline
\end{tabular}

HALFCELL READINGS FOR COATED FIBER REINFORCEMENT

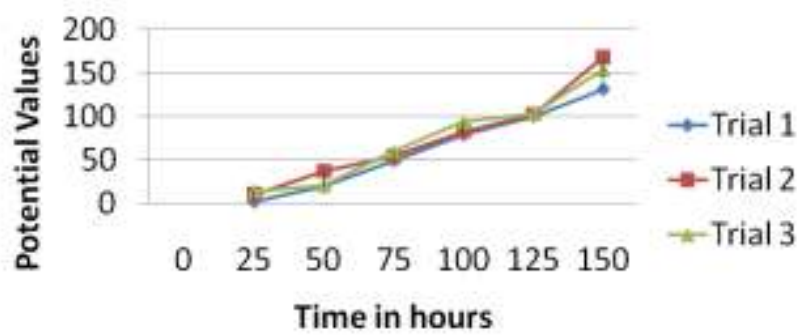

Fig 7. Half-cell reading for coated reinforcement with fiber

\section{CONCLUSION}

In the present work an attempt was made to study the effectiveness of corrosion protection of rebar using coating materials and fibre concrete in M 25 grade of concrete. The efficiency of the coating material was compared with that of the uncoated rebar. The weight loss method was used to determine the percentage of corrosion. The corrosion of the concrete is taken as the end point of the corrosion process. The rate of corrosion was monitored using the saturated calomel as the references electrodes alternate measurement. The rod diameter spacing and cover are kept over constant.

- The coated rebar with fibre is preventing more corrosion than other specimens.

- Fibre gives $40 \%$ better strength than conventional concrete

The coated bars of reinforcement are less corroded than the uncoated bars of reinforcement. The corrosion protective quality of R.C. slabs in M 25 grade concrete with fibre seems to be good with protective coating on rebar.

\section{REFERENCES}

[1] Dhir R.K, Jones M.R and McCathy.M.J (March 1994) "Chloride-Induced Reinforcement Corrosion", Magazine Of Concrete Research', 46, No.169, Dec 269 - 277

[2] DugarteM.Sagties A.A, Powers R.G., Lasa, (2007) Evaluation of Point Anodes for Corrosion Prevention in Reinforced Concrete", Paper No, 07304, 14 pp., Corrosion. [3]Gonzalez, J.A et al (1998) "The Effect of Chloride Ions on the Corrosion of Steel Reinforcements Embedded in Concrete Structures", Magazine of Concrete Research, Vol 50.no.pp.190-197.

[4]Gonzalez, J.A et al (March 1990) "The Mechanism of Steel Corrosion in Concrete. The Role of Oxygen Diffusion", Magazine of Concrete Research, Vol.42, No. PP.23-27.

[5]Jagadeesan, K. (2003) "Experimental effect on corrosion on the reinforced concrete beams", Ph.D., Thesis, Anna University.

[6]Jumaat.M.Z, and Rahman.M.M and Alam .M.A. (June 2010) "Flexural Strengthening of RC Structures", 'International Journal of the Physical Sciences' Vol.5 (6), pp.619-625.

[7]Kamashwari.B, Kumar.K, Sivakumar.S (July-sep 2010) "Effect Of Reinforcement Corrosion on Flexural Behaviour of Concrete Beams", Amrapali, 'Technical Journal of Civil Engineering', Vol-I.

[8]Lamyaamleh and saeedmirza (May 1995)"Corrosion Influence On Bond Between Steel And Concrete", Indian Concrete Journal,Vol69, No5

[9]Leema Rose, suguna.K and Ragunath.P.N (2009) "Strengthening of Corrosion Damaged Reinforced Concrete Beams with Glass Fiber Polymer Laminate", 'Journal Of Computer Sciences' 5(6):435-439.

[10]Makita M., Mori, Y., and Katawaki, k (1980) "Marine corrosion -behaviour of reinforced exposed to Tokyo bey", 
performance of concrete in marine environment SP 65-16, ACI deposit, pp.271-289.

[11]Sekar.A.S.S, saraswathy .V and Parthiban.G.T (2007)

Cathodic Protection of Steel in Concrete Using Conductive Polymer Overlays, IntJ.Electrochem., (2) 872-882.

[12]Srinivasan.S (1994) et al "Corrosion Monitoring of Marine Concrete Structures- on Appraisal”, Indian Concrete Journal Vol 68, No.1.

[13]Sukumar P. (2000)"Experimental Investigation On The Reduction Of Corrosion In RCC Using Epoxy Zinc Coated Rebars". M.E, thesis Coimbatore institute of technology [14]Thangavel K.et al (1995) "Influence of Protective Coating on Steel Concrete Bond" Indian Concrete Journal, Vol 69 No.5pp289-293. 